\title{
GARNET PERIDOTITE XENOLITHS FROM THE KOFFIEFONTEIN MINE, SOUTH AFRICA
}

\author{
Margaret Hanrahan ${ }^{1}$, Thomas Stachel ${ }^{1}$, Gerhard P. Brey ${ }^{2}$, Yann Lahaye ${ }^{2}$ \\ ${ }^{1}$ University of Alberta, Edmonton, Canada; ${ }^{2}$ University of Frankfurt, Germany
}

\section{INTRODUCTION}

The Koffiefontein pipe in South Africa is a Group 1 kimberlite of Cretaceous age (about 80-95 Ma; Dawson, 1989) and it is located about $130 \mathrm{~km} \mathrm{SE} \mathrm{from}$ the town of Kimberly in the interior of Kaapvaal Craton. Although being a major diamond mine, surprisingly few studies have been conducted on the mantle sample contained in the Koffiefontein kimberlite. Published results are only available on Koffiefontein diamonds and their syngenetic mineral inclusion content (Rickard et al., 1989, Deines et al., 1991). The absence of studies on mantle xenoliths may reflect a generally smaller size and higher degrees of alteration of peridotite inclusions in this kimberlite relative to the Kimberley area. In a recent sampling effort we were able to collect in excess of 50 peridotite xenoliths at Koffiefontein and of these, 21 samples were selected for further study of their mineral chemistry by electron microprobe (major and minor elements) and laser ablation ICP-MS (trace elements).

\section{PETROGRAPHY}

Based on petrographic examination and the pressuretemperature (PT) estimates described below the 21 xenoliths could be subdivided into five categories:

Spinel Peridotite (1 sample): characterized by the presence of reddish aluminous spinel.

Low PT, coarse peridotites (8 samples): Olivines are strain free, garnets, if present, show strong kelyphitic alteration, clinopyroxene exsolution from orthopyroxene is common and reddish aluminous spinel is absent.

High PT, coarse peridotites (4 samples): Samples are generally strongly altered with much of the olivine being replaced by pseudomorphs of serpentine. Relicts of remaining olivine are stain free. Oxides are abundant in about half of the samples and appear to be of secondary origin.

High PT, (textually) transitional peridotites (3 samples): Characteristic for this group is a bimodal crystal size distribution. In contrast to the group of sheared peridotites described below, the dynamically recrystallized fine grained olivine does not form the matrix but is limited to apparently disconnected streaks and lenses. Olivine macrocrysts are typically strained.

High PT, sheared peridotites (3 samples): Large porphyroclasts (typically of pyroxene and garnet) are accompanied by pressure shadows and (in the case on anisotropic minerals) may show distinct polygonization.

\section{GEOTHERMOBAROMETRY}

Temperature estimates based on the clinopyroxene goethermobarometer of Nimis and Taylor (2000) were obtained for 18 samples and are shown in Figure 1. Estimates based on additional combinations of thermometers and barometers (e.g. $\mathrm{T}_{\mathrm{BKN}}[\mathrm{cpx}$-opx] with $\mathrm{P}_{\mathrm{BKN}}$ [grt-opx]) gave similar results. The single phase cpx geothermobarometer of Nimis and Taylor (2000) was chosen as our preferred method as it is applicable to the largest number of xenoliths.

The results presented in Figure 1 show a correlation with the petrographic observations given above. Two

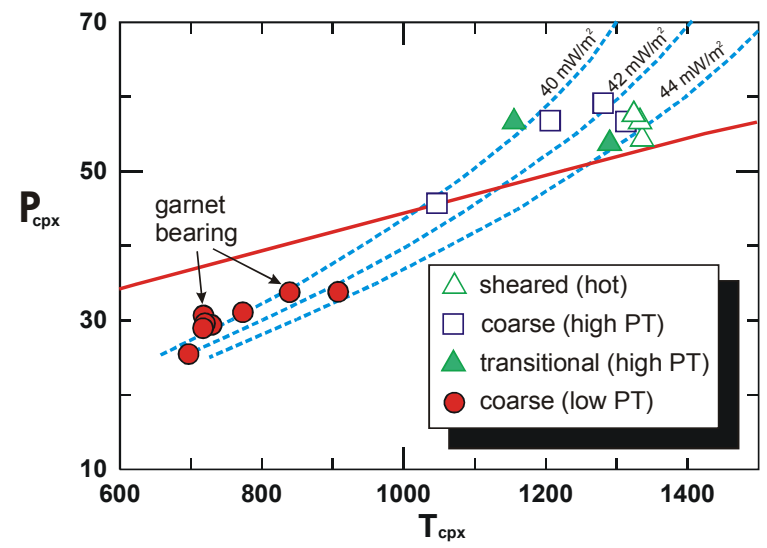

Figure 1: PT estimates for xenoliths from Koffiefontein based on the single phase cpx geothermobarometer of Nimis and Taylor (2000). The $\mathrm{Cr}$ in cpx barometer was applied to all coarse peridotites, assuming derivation from the garnet stability field and equilibration with garnet even though garnet was not observed in every thin section of the low PT group. The symbol legend will be consistent through the abstract. 
main groups of data emerge from Figure 1: (i) a low PT group, comprising coarse garnet bearing and apparently garnet free peridotites (the one sample containing aluminous spinel also falls into this group, however the $\mathrm{Cr}$ in cpx barometer requires equilibration with garnet and thus it cannot be included in the plot) and (ii) a high PT group extending into the diamond stability field with coarse, transitional and sheared textures. The samples that fall into the diamond stability field can be further subdivided into xenoliths plotting along a typical cratonic geotherm (40-42 $\mathrm{mW} / \mathrm{m}^{2}$ ), and a second group that extends to higher temperatures. The latter group, which in other localities such as Taba Putsoa is exclusively composed of sheared peridotite samples (e.g. Brey 1989), is not related to the presence of a second, elevated geotherm, but is evidence of localized and short-lived thermal perturbances. Brey (1989) used $\mathrm{Ca}$ in olivine to establish that peridotite samples plotting off the local goetherm were entrained in kimberlite before reaching thermal equilibrium and thus established a temporal relationship between these short lived thermal perturbances and kimberlite activity. The "coldest" samples in the high pressure group reflect the thermal conditions prior to these disturbances and thus a local geotherm of $40-42 \mathrm{~mW} / \mathrm{m}^{2}$ may be derived based on coarse peridotite samples. The high temperature sheared peridotites lie about $100{ }^{\circ} \mathrm{C}$ above this local

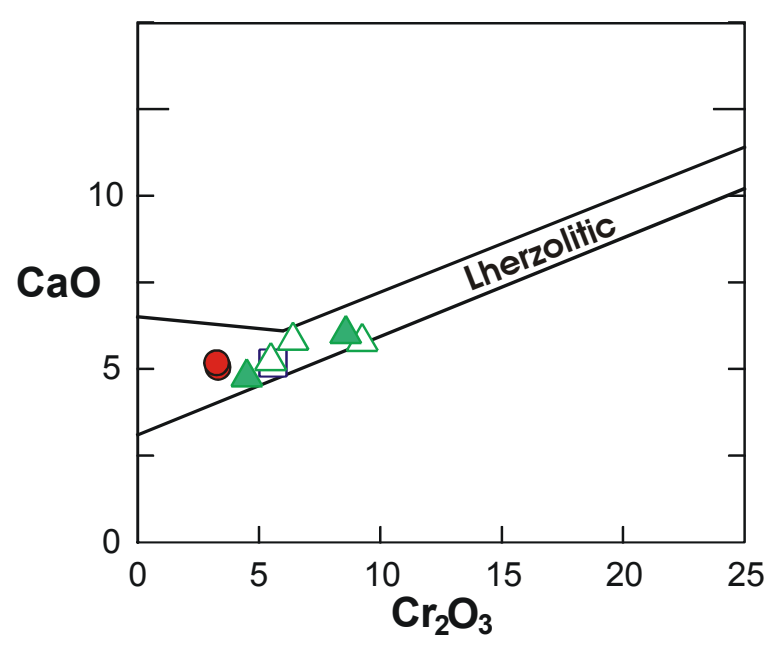

Figure 2: $\mathrm{CaO}$ vs $\mathrm{Cr}_{2} \mathrm{O}_{3}$ garnets showing lherzolitic trend. For each xenolith an average composition is shown (symbols as in Fig. 1). geotherm.

Our data agree well with previous observations (e.g. Harte, 1983) made on xenoliths from many kimberlites in South Africa and Lesotho, frequently showing a similar separation of temperature estimates into two groups.

\section{MAJOR ELEMENT ANALYSES}

Based on a $\mathrm{CaO}$ vs. plot $\mathrm{Cr}_{2} \mathrm{O}_{3}$ (Figure 2), all of the garnets analyzed belong to the lherzolitic paragenesis. Garnets derived from a primitive peridotite composition would have $\mathrm{Cr}_{2} \mathrm{O}_{3}$ contents of about $2 \mathrm{wt} \%$, which is not the case for our samples. Garnets from two low PT, coarse peridotite samples have $\mathrm{Cr}_{2} \mathrm{O}_{3}$ contents of about $3.5 \mathrm{wt} \%$, which approximately corresponds to the maximum solubility of the knorringite component in the garnet structure at the relevant pressures (about 30 kbar). The high chromium contents of garnets formed at higher pressures reflect a high $\mathrm{Cr} / \mathrm{Al}$ ratio in their sources, which indicates high degrees of previous melt depletion at low pressures.

\section{TRACE ELEMENT ANALYSES}

\section{Garnet}

Figure 3 shows the $\mathrm{REE}_{\mathrm{N}}(\mathrm{N}=$ chondrite normalized) patterns of the peridotitic garnets. Garnets from low PT, coarse samples show depletion relative to C1chondrite for the LREE, a steep positive slope ensues to the MREE, followed by a slope decrease and almost flattening towards the HREE. The more enriched of the two samples plots close to the $\mathrm{REE}_{\mathrm{N}}$ pattern for garnet from the one high PT, coarse peridotite sample analyzed and both patterns are very similar to typical REE trends for lherzolitic garnets observed elsewhere (e.g. Stachel et al., 1998). Of the high PT, transitional samples, garnet compositions of one sample follow the typical lherzolite trend, while the other is sinusoidal. Garnets from the high PT, sheared peridotites demonstrate the largest variation in REE patterns ranging from distinctly sinusoidal, over moderately sinusoidal to the characteristic flat $\mathrm{MREE}_{\mathrm{N}}-\mathrm{HREE}_{\mathrm{N}}$ pattern (at very high MREE-HREE concentrations) typical for lherzolites. 


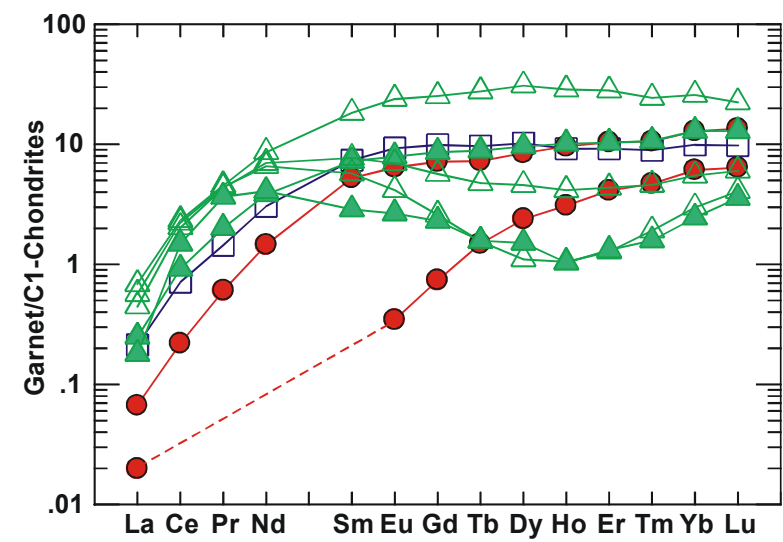

Figure 3: REE concentrations in peridotitic garnets normalized to the C1-chondrite composition of McDonough and Sun (1995). Symbols as in Fig. 1.

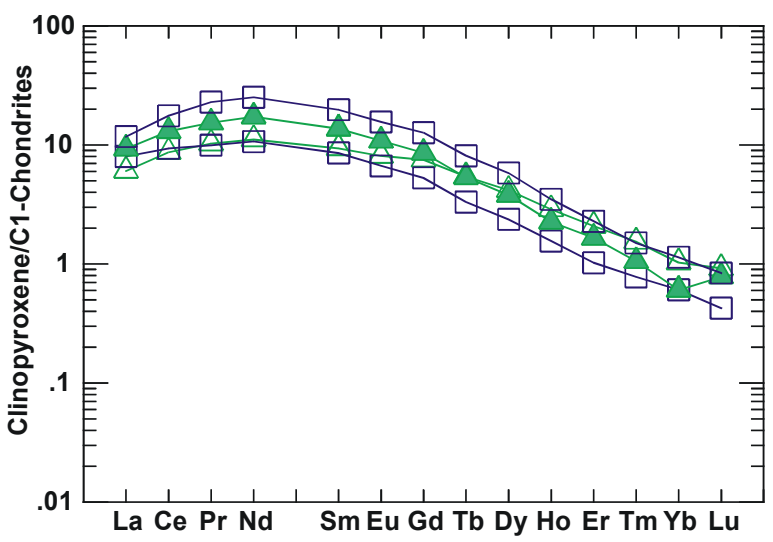

Figure 5: REE concentrations in clinopyroxenes normalized to C1-chondrite composition of McDonough and Sun (1995). Symbols as in Fig. 1.

When plotted against a primitive garnet composition (J4 of Jagoutz and Spettel, unpubl., Figure 4), the REE patterns appear fairly flat and show less depletion in the LREE. However, this generalization does not hold for the low PT, coarse peridotite samples, where garnet shows a marked decrease in the LREE relative to J4. Garnet from the high PT, coarse peridotite sample shows a slight positive slope from $\mathrm{Ce}$ to $\mathrm{Sm}$, followed by a roughly horizontal pattern for the MREE and HREE, which again is indicative for minor LREE depletion. The high PT, transitional samples show two distinct garnet patterns; the first is fairly flat with a minor peak at $\mathrm{Sm}$, the second is sinusoidal showing a primitive signature in the LREE and depletion relative to J4 in the MREE and HREE. Once again the garnets from the high PT, sheared peridotites show the largest

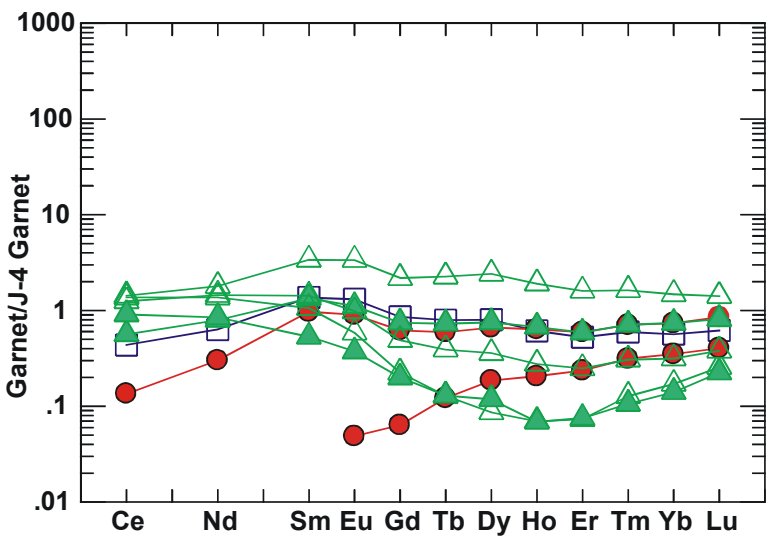

Figure 4: REE concentrations in peridotitic garnets normalized to $\mathrm{J} 4$ (garnet composition from primitive bulk rock composition, xenolith J4 from Jagersfontein) of Jagoutz and Spettel (unpubl.). Symbols as in Fig. 1.

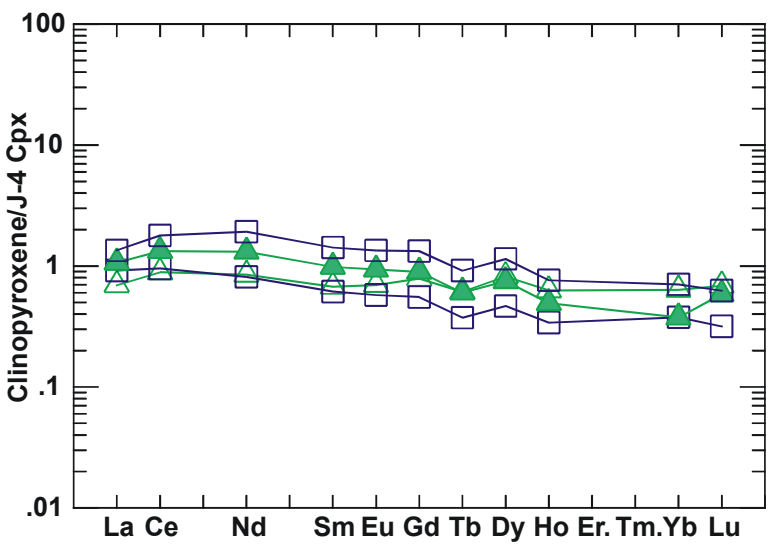

Figure 6: REE concentrations in clinopyroxenes normalized to J4 (clinopyroxene composition from primitive bulk rock composition, xenolith J4 from Jagersfontein) of Jagoutz and Spettel (unpubl.). Symbols as in Fig. 1.

spread. For the LREE up to Nd the pattern are flat but slightly enriched relative to J4, for the MREE and HREE the four patterns separate, one becoming sinusoidal, another moderately sinusoidal and two are fairly flat but differ significantly in their MREE-HREE abundances.

\section{Clinopyroxene}

All of the clinopyroxenes analyzed (only samples of the high PT group are represented) yielded very similar $\mathrm{REE}_{\mathrm{N}}$ patterns (Figure 5). From 10 times chondritic abundances for $\mathrm{La}$, the patterns show positive slopes within the LREE peaking at $\mathrm{Nd}$ and then steadily decrease towards the MREE and HREE. Normalization 
to primitive clinopyroxene from J4 (Jagoutz and Spettel, unpubl.) (Figure 6) shows virtually flat REE patterns with primitive abundances.

\section{CONCLUSIONS}

Peridotite xenoliths from the Koffiefontein kimberlite agree well with data obtained from other localities in South Africa and Lesotho: while both low PT and high PT, coarse peridotite samples plot along a typical cratonic geotherm (corresponding to $40-42 \mathrm{~mW} / \mathrm{m}^{2}$ surface heat flow), the high PT, sheared samples lie at temperatures $100{ }^{\circ} \mathrm{C}$ above this local geotherm. The sheared peridotite samples are inferred to represent localized and short-lived thermal perturbances related to magmatic intrusions penecontemporaneous to kimberlite activity

Despite depleted major element characteristics (e.g. high $\mathrm{Cr}$ in garnet) lherzolitic garnets and clinopyroxenes show REE concentrations that are only moderately depleted, primitive or even slightly enriched. This documents pervasive metasomatic reenrichment in the sub-cratonic lithospheric mantle beneath Koffiefontein, which is not restricted to the group of hot and sheared peridotites.

\section{ACKNOWLEDGEMENTS}

We are very grateful for the hospitality and the magnificent support we experienced during our sample trip from DeBeers Consolidated Mines Ltd, in particular from Bill McKechnie, Jock Robey and the geologists in the Koffiefontein Mine (Deolney and Richard). Sergei Matveev is thanked for his assistance with the microprobe analyses.

\section{REFERENCES}

Brey, G.P., 1989. Geothermobarometry for lherzolites: experiments from 10 to $60 \mathrm{~kb}$, new thermobarometers and application to natural rocks. Habilitation Thesis Thesis, TU, Darmstadt, 227 pp.

Dawson, J.B., 1989. Geographic and time distribution of kimberlites and lamproites: relationship to tectonic processes. In: J. Ross and et al. (Editors), Kimberlites and related rocks. GSA Spec Publ 14. Blackwell, Carlton, pp. 323-342.

Deines, P., Harris, J.W. and Gurney, J.J., 1991. The carbon isotopic composition and nitrogen content of lithospheric and atmospheric diamonds from the Jagersfontein and Koffiefontein kimberlite, South Africa. Geochim. Cosmochim. Acta 55: 2615-2625.

Harte, B., 1983. Mantle peridotites and processes -- the kimberlite sample. In: C.J. Hawkesworth and M.J. Norry (Editors), Continental basalts and mantle xenoliths. Shiva Publishing Ltd, Nantwich, pp. 46-91.

McDonough, W.F. and Sun, S.-S., 1995. The composition of the Earth. Chem. Geol., 120: 223-253.

Nimis, P. and Taylor, W.R., 2000. Single clinopyroxene thermobarometry for garnet peridotites. Part I. Calibration and testing of a Cr-in-Cpx barometer and an enstatite-in-Cpx thermometer. Contrib. Mineral. Petrol., 139(5): 541-554.

Pollack, H.N. and Chapman, D.S., 1977. On the regional variation of heat flow, geotherms, and lithospheric thickness. Tectonophysics, 38: 279-296.

Stachel, T., Viljoen, K.S., Brey, G. and Harris, J.W., 1998. Metasomatic processes in lherzolitic and harzburgitic domains of diamondiferous lithospheric mantle: REE in garnets from xenoliths and inclusions in diamonds. Earth. Planet. Sci. Lett., 159(1-2): 1-12.

Rickard, R.S., Harris, J.W., Gurney, J.J. and Cardoso, P., 1989. Mineral inclusions from Koffiefontein mine. GSA Spec. Publ., 14: 1054-1062.

Contact: MA Hanrahan, 6838112 A St., Edmonton, AB, T6H-3K6, Canada. E-mail: marg_hanrahan@hotmail.com 